\title{
A FOURTEENTH-CENTURY HOSPITALLER ACCOUNT BOOK FROM HISPANIA
}

\author{
THERESA M. VANN \\ Hill Monastic Manuscript Library \\ Saint John's University \\ Collegeville, MN (USA)
}

\section{CONTENTS}

1. The account book.- 2. Organization of Hospitaller priories.- 3. Juan de Heredia.

The history of the military religious orders in the fourteenth century is an inviting field of study, with extensive amounts of rich archival material. Regina Sáinz de la Maza has made important contributions editing and publishing material pertaining to military religious orders in the Crown of Aragon'. Yet, as Derek Lomax has observed, the spectacular dissolution of the Templars in 1312 has distracted historians from the subsequent distribution of its properties ${ }^{2}$. The Order of the Hospital received most of the properties of the Temple following this massive, European-wide

\footnotetext{
'See, for example, Regina SÁINZ DE LA MAZA LASOLI, La Orden de Santiago en la Corona de Aragón. La encomienda de Montalbán (1210-1327), Zaragoza, 1980; La orden de Santiago en la Corona de Aragón, II. La Encomienda de Montalbán bajo Vidal de Vilanova (1327-1357), Zaragoza, 1988; La Orden de San Jorge de Alfama. Aproximación a su historia, Barcelona, 1990; and El Monasterio de Sijena. Catálogo de documentos del Archivo de la Corona de Aragón, I (1208-1348), Barcelona, 1994.

${ }^{2}$ Derek Lomax, Las Órdenes Militares en la Península Ibérica durante la Edad Media, Salamanca, 1976, p. 28.

"Anuario de Estudios Medievales", 28 (1998)
} 
reallocation of lands and income, except in the Iberian peninsula, where the kings of Aragon and Portugal successfully diverted the former Templar properties to the newly-created military religious orders of Montesa (in Valencia) and Christo (in Portugal).

As a result of the reorganization, the Order of the Hospital surrendered its properties in Valencia to the new Order of Montesa and reorganized its priories in Spain and France. This reorganization of the Order's lands and properties in Spain after the dissolution of the Order of the Temple requires a systematic study. The vast amount of materials from the archives of the priories of Catalonia and Aragon, which are housed in Barcelona and Madrid, have not been mined. The work of Joaquim Miret y Sans (Les cases de Templers y Hospitalers en Catalunya) and Alan Forey (The Templars in the Corona de Aragón) are preliminary studies ${ }^{3}$. Joseph Delaville le Roulx and Derek Lomax have outlined the contents of these archives, and some cartularies have been published, but there is still work to be done ${ }^{4}$.

Another source for the Order of the Hospital in Iberia is the central archives of the Order of the Hospital of St. John of Jerusalem, which are located on the island of Malta and contain materials from the Hospitaller's priories all over Europe. This rich collection is also remarkable for the gaps in its holdings. We know that just about all of the Order's financial records prior to the sixteenth century are destroyed. We also know that the records for the Spanish priories are very scant in Malta, although unlike the lost records of the treasury we do not know if these records ever existed in the main archives. The massive fonds for the Order of the Hospital that survive in Madrid and Barcelona remain the best source for the Spanish priories, although the Hospitaller records for northern, or Old Catalonia, are dispersed and difficult to find ${ }^{5}$.

\footnotetext{
${ }^{3}$ Joaquim MIRET Y SANS, Les cases de Templars y Hospitalers en Catalunya, Barcelona, 1910; Alan Forey The Templars in the Corona de Aragón, Oxford, 1973.

${ }^{4}$ See Lomax, Las Órdenes Militares en la Península Ibérica; Joseph Delaville Le RoulX, Les archives de l'Ordre de l'Hôpital dans la Péninsule Ibérique, "Nouvelles Archives des Missions Scientifiques et Littéraires", IV (1893), pp. 1-283. In addition to the contributions of Regina Sáinz de la MaZa Lasoli, see also Santos A. García LarRagueta, El Gran Priorado de Navarra de la Orden de San Juan de Jerusalem, 2 vols., Pamplona, 1957, and Carlos de Ayala Martínez, Libro de privilegios de la Orden de San Juan de Jerusalén en Castilla y León (siglos xii-xv), Madrid, 1995.

${ }^{5}$ Paul Freedman, Military Orders in Osona during the Twelfth and Thirteenth Centuries “Acta Historica et Archaeologica Mediaevalia”, III (1982), p. 57.
} 
The discovery of a previously unknown fourteenth-century account book of the responsions paid by the priory of St. Gilles, housed today in the Order's main archives in Malta, provides some information about the income and organization of north Catalan Hospitaller priories. Unlike other Hospitaller financial records, which are summaries of yearly totals from groups of priories, this account book shows how the Order kept accounts and how much each house owed. It reveals that the organization of estates into priories was centered on the affiliation of the prior, not the geographical location of the priory. This explains how the order organized and administered its priories, including former Templar estates, in Catalonia and Languedoc.

Establishing the importance of this discovery was not easy. There is nothing else like the account book in the main archives of the Order. Earlier archivists had misidentified the book or omitted it from inventories and hand lists. The list of priories in the account book does not correspond to published lists of Hospitaller properties dating after the dissolution of the Order of the Temple. Most interestingly, the account book covers the period of time immediately following the death in 1396 of Juan Fernandez de Heredia, the great Aragonese prior and Master of the Order of the Hospital, and includes properties assigned to his followers. Therefore, I shall briefly describe the account book and its historical context. I will explain the new information this account book provides about the allocation and organization of the system of Hospitaller properties in Catalonia. Finally, I will conclude with a theory explaining its compilation.

\section{THE ACCOUNT BOOK}

The account book (Archive 2190) is housed in Section 14, where it forms part of the records of the Langue of Aragon. It is the only item that predates the year 1500 in that section of the archive ${ }^{6}$. Delaville le Roulx,

\footnotetext{
${ }^{6}$ Malta, Valletta, National Library, Section 14, Archive 2190. In comparison with other sections of the Malta archives, Section 14 contains very little material from the Iberian Langues, and most of the manuscripts date from the $16^{\text {th }}$ through the $18^{\text {th }}$ century. The other items from the Langue of Aragon in this section of the archive are:

Vol. 2185, Roll of the Knights, Chaplains and Serving Brothers of the Langue 1789

Vol. 2186, Ditto, 1796
} 
the nineteenth-century historian of the order, does not mention the account book in any of his inventories ${ }^{7}$. Joseph Galea, who prepared a hand list of the archives in 1974, identified it as "Admissions into the Langue of Spain" with no date ${ }^{8}$. It seems that the last people who examined the account book were a Mr. Millward, a Reverend Larking, and an unknown Scotsman who prepared the Camden Society publication of an inventory of the English Priory in $1857^{\circ}$. The two manuscript books were (and are) shelved next to each other in the same cupboard. Although the Camden Society editors thought both books were very similar, they only published the English records.

The Hill Monastic Manuscript Library's microfilming project of the Archives of the Knights of Malta filmed the account book in 1993 and entitled the volume Receptarum linguae hispania, assigning it a date of the 14th-15th century ${ }^{10}$. I came across it while preparing a modern hand list of the archives and I realized its importance for the study of the military orders in Iberia. I could not determine if the new title, Receptarum linguae hispania, was an assigned title or taken from the outer binding (which was not microfilmed). Receptarum linguae hispania, however, reflects the account book's representation of properties in Old Catalonia and Languedoc. According to the incipit, the book is an accounting in the year 1397 of the

Vol. 2187 Miscellaneous papers concerning the commanderies of Aragon, Catalunya and Navarre, 1750-1797

Vol. 2189 Miscellaneous documents concerning the foundation of the langue

Vol. 2190 (misidentified as Admissions into the Langue of Spain) $14^{\text {th }}$ century accounts from Hispania

'Joseph Delaville Le RoulX, Les Archives la bibliotheque et le trésor de l'ordre de SaintJean de Jérusalem a Malte, Paris, 1883, does not describe Section 14 of the Order's archives.

${ }^{8}$ Joseph Galea, A Catalogue of the Manuscript Volumes of the Archives of the Order of Saint John of Jerusalem Preserved in the Royal Malta Library, Typescript, Valletta, 1974, p. 153.

${ }^{9}$ Lambert B. LARKING, The Knights Hospitallers in England: Being The Report of Prior Philip de Thame to the Grand Master Elyan de Villanova for A. D. 1338. Camden Society, no. 65 , London, 1857, p. v: "There is also a volume of the fifteenth century, containing the accounts of the Commanderies. It is a continuation of an older and still more interesting volume which has, by some means, found its way into the Public Library. The latter gives the accounts of the property belonging to the Order in England and Scotland. Unfortunately these accounts are very difficult to decipher..." The Camden Society published Archive 2191, which is shelved right next to Archive 2190.

${ }^{10}$ Hill Monastic Manuscript Library inventory description of Malta, National Library, Archive 2190, Valletta, 1993: Receptarum linguae hispania, dated 14th-15th century, 300 by $220 \mathrm{~mm}$, bound in parchment, 135 folios, with folios $7-11,34,56,82-84,133$, and 135 blank. Parchment cover was a reused document. Volume contains one loose document. 
responsions of the Spanish goods of the Priory of St. Gilles, made to the Treasury of the Convent of Rhodes and to Rostan Bosio, the treasurer. The manuscript annually lists the houses and the payments of the commanders until 1402. It concludes with a rudimentary accounting of the spoils of deceased priors and other income from these particular properties. The properties are organized by senescalia (French royal administrative units), priories, and houses. The account book was written in French, in Rhodes (the same hand appears in the French entries in the Liber bullarum for $1399^{11}$ ) and, judging from erasures and corrections, is a good copy from drafts of receipts.

Archive 2190, Receptarum linguae hispania, appears very similar to the 1338 visitation of the English Priory that the Camden Society published. Both manuscripts were composed in Rhodes, by someone who was not used to the spelling of local place names. Both are heavily abbreviated, in a fourteenth-century secretarial hand that is not easy to read. But there are essential differences, some of which are superficial. The account book from the English priory was written in Latin, and it includes a thorough inventory of all the sources of income. Archive 2190 was written in French, and is an unadorned accounting of the amounts of responsions paid and owed by the commanders of the priories. It lists each priory but omits such sources of income as mills and farms that appear in the English accounts. The essential difference is in the origin of the two account books. The English manuscript was prepared when the Chapter General ordered all priories in 1330 to prepare an inventory of their estates and send a copy to Rhodes ${ }^{12}$. Archive 2190 reports the yearly responsions that priories paid into the Treasury. The Master's bullarum and the proceedings of the Chapter General frequently refer to these payments, although detailed accounts rarely survive. Archive 2190 is, like Archive 48, an important detailed record in the Malta archives of responsions paid into the Order's treasury in Rhodes ${ }^{13}$. As such it shows that the commanders of each house were personally responsible for paying

\footnotetext{
"Malta, Valletta, National Library, Section 5, Archive 330, Liber bullarum M. Magistri Fratris Philiberti de Naillac; 1399, Priory of St. Gilles, fol. 37 r.

${ }^{12}$ Anthony LUTTRELl, Hospitaller's Historical Activities, 1291-1400, The Hospitallers in Cyprus, Rhodes, Greece, and the West 1291-1440, London, 1978, p. 7; Malta, Valletta, National Library, Section 2, Archive 280, fol. 12 r.

${ }^{13}$ Malta, Valletta, National Library, Section 1, Archive 48, Livre des receptes des revenus du Grand Maitre et Couvent de Rodes sur tous les priores et comandes. Fernandes d'Eredia Maitre Rodes. 226 fols.
} 
responsions, and if one of their houses fell short the commander had to make up the difference from his other income. This explains the independence of the priories from the Master, who could not be assured of receiving responsions unless he had a personal connection with the commander.

\section{ORGANIZATION OF HOSPITALLER PRIORIES}

As the title Receptarum linguae hispania suggests, Archive 2190 contains Catalan houses and commandaries, which does not coincide with published records of the disposal of the Spanish properties of St. Gilles. St. Gilles is the oldest Hospitaller overseas priory, founded in 1115. At some point in the twelfth century the Order of the Hospital formally organized its overseas priories into Langues or Tongues that approximated national boundaries to simplify administration. All the priories were required to pay money, called responsions, into the Order's main treasury. The responsions became the Order's primary means of support after the loss of all its properties in the Latin Kingdoms in the East by 1291. The payment of responsions became the dominant theme in relations between the Master and the overseas priors by the mid thirteenth century and continued through the fourteenth century. Only the Spanish priories could resist the payment of responsions because they fought the Muslims in Spain, and this is generally accepted as the reason the Orders of the Temple and the Hospital did not want properties on the Iberian Christian-Muslim frontiers.

The priory of St. Gilles straddled the boundaries between modern France and Spain. Today, historians of the Order of the Hospital count it among the "French" priories of the Order ${ }^{14}$. In the $14^{\text {th }}$ century, St. Gilles included Catalonia and the south of France. Most of the properties in the account book were in old Catalonia, especially the province of Rousillion, and in Languedoc. The Priory of St. Gilles included Spanish properties until the creation of specifically Spanish priories: the Castellany of Amposta (Aragon) in 1149/1154, the Priory of Navarre (1185), the Priory of Castile and León (founded ca. 1149) and the priory of Portugal (independent from

\footnotetext{
${ }^{14}$ See H. J. SIRE, The Knights of Malta, Yale, 1994, p. 114, for map of the priory of St. Gilles following modern national boundaries.
} 
Castile, late twelfth century ${ }^{15}$. Although St. Gilles lost estates to the new Spanish priories, it increased its holdings during the Albigensian crusade of the thirteenth century. The Order of the Hospital also received the estates of the Templars after the suppression of the Order in 1312, except in Spain. There the kings of Aragon and Portugal used the former Templar properties to create the military religious orders of Montesa (in Valencia) and Christo (in Portugal) ${ }^{16}$. This massive acquisition of Templar properties in the fourteenth century also caused a reorganization of the Hospitaller system of overseas priories. Because of the creation of the Order of Montesa, the Order surrendered its estates in Valencia and created the new Priory of Catalonia in 1319 out of the Spanish estates of St. Gilles ${ }^{17}$. The Hospitallers also created new French priories in Aquitaine, Champagne, and Toulouse in 1315.

The boundaries between the new priories remained fluid through the fourteenth century. The formal earliest listing of the priories in the Liber bullarum of the Masters, dating from 1346, combines the priories of Castile, Portugal, and Navarre ${ }^{18}$. The Liber bullarum of 1399 categorized Aragon and the Castellany of Amposta as two separate priories, but combined Castile, Portugal, and Navarre with Catalonia as a separate priory ${ }^{19}$. These changes were not administrative divisions created by the Master; instead, they reflect the machinations of individual commanders who increased their wealth by amassing estates and baliwicks ${ }^{20}$. The Langue affiliation of the commander determined the Langue affiliation of the priory. Langue affiliation based upon geographical location was not firmly established until the sixteenth century.

For example, Archive 2190 contains at least one estate that the Master had assigned to the priory of Catalonia. This is the commandary of

\footnotetext{
${ }^{15}$ Jonathan RILEY-SMITH, The Knights of St. John in Jerusalem and Cyprus 1050-1310, London, 1967, p. 356; García Larragueta, 1:55.

${ }^{16}$ See Joseph O'Callaghan, Las definiciones medievales de la orden de Montesa (13261468), in "The Spanish Military Order of Calatrava and its Affiliates", London, 1975, pp. 213 215, for the origins of Montesa.

${ }^{17}$ Ibid.

${ }^{18}$ Malta, Valletta, National Library, Liber bullarum, Archive 316 (1346), fol. 3 r.

${ }^{19}$ Malta, Valletta, National Library, Liber bullarum, Archive 330 (1399), fol. 2 r.

${ }^{20}$ Sire, p. 120 , recounts the example of Guillaume de Reillane, the prior of St. Gilles and Provence in 1330 , who united the two priories under one master even though the Master intended to separate them.
} 
Bajoles in Catalonia, in the province of Roussillon. Bajoles is unmistakably a Catalan estate. It had originally been a Templar property attached to the commandary of MasDéu, in Roussillon ${ }^{21}$. The Order of the Hospital in Roussillon acquired it in $1211^{22}$. When the Priory of Catalonia was created in 1319, it received the remaining Templar houses in Roussillon, including Bajoles. In 1376 the Priory of Catalonia conducted an inventory of the house in Bajoles ${ }^{23}$. Master Juan de Heredia ordered in 1392 that the commanders of specific houses, including Bajoles in the priory of Catalonia, pay their responsions into the treasury ${ }^{24}$. Yet this account book from 1397 includes Bajoles as part of the priory of St. Gilles, not the priory of Catalonia.

This inclusion of Bajoles was not an error made in the Treasury at Rhodes, nor does it reflect an essential conservatism of Rhodian record keeping. Instead, it shows that the new Master, Philip de Naillac, reorganized the Order after the death of Juan de Heredia in 1396. In 1391 the commander of Bajoles was Pere de Vilafranca, the Grand Prior of Catalonia $^{25}$. In 1397 the commander of Bajoles was Raymond de Lescura, Grand Prior of Toulouse in 1393 and commander of several commanderies of St. Gilles $^{26}$. The special relationship Juan de Heredia had created between the Order of the Hospital and the Crown of Aragon affected the payment of responsions by Catalan and Aragonese Hospitaller priories. After he died in 1396, the new Master Philip de Naillac used his right of appointment for Bajoles to assign the priory to a Frenchman, not a Catalan. The new prior became personally responsible for the debts of Bajoles, and for the year 1397 he attached it to his other priories in St. Gilles\France.

\footnotetext{
79.

${ }^{21}$ Antoni Pladevall and F. Català RoCA, Els Monestirs Catalans, Barcelona, 1970, p.

${ }^{22}$ Ibid.

${ }^{23}$ Miret i Sans, pp. 560-61, no. 8.

${ }^{24}$ Dela VILLE Le Roulx, Les Hospitaliers à Rhodes jusqu'à la mort de Philibert de Naillac: 1310-1421, Paris, 1913, pp. 381-383, no. 11.

${ }^{25}$ Ibid., pp. 225, 229; MiRET I SANS, p. 524.

${ }^{26}$ Malta, Valletta, National Library, Archive 2190, $1 \mathrm{r}$.
} 


\section{JUAN DE HEREDIA}

Anthony Luttrell argues convincingly that the Aragonese Hospitallers always had closer ties to the crown of Aragon than they did to the convent at Rhodes. The Hospitallers benefitted from the spoils of the reconquest, while Rhodes was distant and controlled by Provençal knights ${ }^{27}$. The Hospitallers in Aragon still paid responsions to the Order's main treasury, but the crown tried to divert this money to its own fight against the Muslims. Additional proof for the distance between the Aragonese Hospitallers and the rest of the Order occurred during the Avignon papacy's crusade against Aragon in 1285, when the Hospitallers in Aragon supported the king against the pope and the rest of the Order. Luttrell finds that the Master in Rhodes began to lose power over the Hospitallers and their resources in Aragon with the suppression of the Templars and by the middle of the century he had lost most of his influence over them.

Other than physical distance, the desire to gain the Templar estates drove a wedge between the Convent in Rhodes and the Crown of Aragon. James II of Aragon realized the possibilities that the Templar properties presented even before the final dissolution. In 1307 James II of Aragon wrote a letter to Clement $\mathrm{V}$, in which he suggested that if the Templars had committed the terrible crimes that they were accused of, that some of their properties in the kingdom of Aragon should be assigned to the female Hospitaller convent of Sijena, where his daughter Blanche was professed ${ }^{28}$. Blanche later became prioress of Sijena from 1321 to 1347. James wrote additional letters concerning the Templar properties until the final allocation in 1319.

The issue of responsions widened the gap between the Aragonese Hospitallers and the Convent in Rhodes. Luttrell found that the Aragonese kings intervened for the Hospitallers in their realms to reduce the amounts of responsions that they paid to Rhodes. In 1329 Alfonso IV proposed that they should reduce the annual responsions of the Castellany and Priory of Aragon to 2,500 florins and 2,000 florins; in 1331 Alfonso declared that

\footnotetext{
${ }^{27}$ See LutTRELl, The Aragonese Crown and the Knights Hospitallers of Rhodes, 1291-1350, in "The Hospitallers in Cyprus, Rhodes, Greece, and the West".

${ }^{28}$ Delaville, Cartulaire de l'ordre des' Hospitalières de Saint-Jean de Jérusalem, 4 vols., Paris, 1894, 4:164-65, letter from James IL of Aragon to Clement V, 29 December 1307, Valencia (Barcelona, ACA, reg. 335, f. 326 [contemporary copy]).
} 
3,000 florins should be the annual limit ${ }^{29}$. In turn the Master of the Order tried to collect the Aragonese responsions. In 1330 the Master ordered that the houses should pay responsions directly to the Treasurer instead of the Prior. He appointed his own lieutenants to priories that were in his own gift, among which was Bajoles ${ }^{30}$. Luttrell was not able to determine if these amounts were paid in full based upon the incomplete financial evidence from the period.

From 1346 until his death in 1396 the Aragonese Hospitaller Juan Fernandez de Heredia became the dominant figure in the Order. His childhood friend Peter the Ceremonious appointed him the Castellan of Amposta in 1346; in 1354 he became the Prior of Castile; and in 1356 he became the Prior of St. Gilles ${ }^{31}$. Heredia lost the last two offices in 1365 when the Provençal Master Raymond Bérenger took a firm stand against Iberian pluralism. But because of Heredia's influence at the papal court in Aragon, Bérenger was not able to collect his arrears of responsions to the Convent in Rhodes. Heredia received a papal appointment to the office of Master of the Order in 1377, over the preferences of the Provencal knights who dominated the Order. As Master, Heredia spent most of his time in the papal court of Avignon, not Rhodes. There he enriched his family and became a noted humanist patron. He supported the Avignon papacy's crusading plans, none of which met with any permanent success.

When Philip de Naillac, prior of Auvergne, became Master in 1396 he tried to collect the responsions and the spoils that the Catalan priory, the Aragonese priory, and the priory of St. Gilles owed ${ }^{32}$. The arrears of St. Gilles may be linked with papal legislation, initially passed by Clement VII and renewed by Benedict XIII (born Pedro de Luna in Aragon) in January 1397 that taxed the prelates and ecclesiastics of Languedoc for the defense of the realm, with the exemption of the Order of the Hospital. The issue of ecclesiastical taxation in Languedoc, combined with the death of Juan de Heredia, suggests that the southern French and northern Catalan houses presented a special problem of arrears to the Convent in Rhodes. Naillac and

\footnotetext{
${ }^{29}$ LutTrell, The Aragonese Crown and the Knights Hospitallers of Rhodes: 1291-1350, "The Hospitallers in Cyprus, Rhodes, Greece, and the West", p. 10.

${ }^{30}$ Ibid., p. 11.

${ }^{31}$ SIRE, pp. 41-42.

${ }^{32}$ Jean Raybaud, Histoire des Grands Prieurs et du Prieuré de Saint-Gilles, Nimes, 1904, p. 354 .
} 
the treasury of the convent wanted to establish what each house owed and what the Master could collect.

Therefore Naillac assigned Bajoles to Raymond de Lescura, Grand Prior of Toulouse, in $1397^{33}$. There is nothing in Miret i Sans; but if Bajoles was removed from the jurisdiction of the Catalan priory for a relatively brief period, it might not show up in the Barcelona archives. According to the account book, Bajoles was six years in arrears and owed some 100 florins (the page is damaged at this point) ${ }^{34}$. Lescura paid approximately half from Bajoles, although his other commandaries paid more than what they owed. Bajoles then drops from the accounts. Sant Nazaire, a dependency of Bajoles, remained in the account book. In 1398 its commander, Pere Planios, paid six florins for the commandary of Peyreneys $\mathrm{s}^{35}$; on behalf of his own commandary he paid 31 florins, which satisfied the amount of responsions ${ }^{36}$. S. Nazaire owed and paid the same amount, 31 florins, in 1399, 1400, and $1401^{37}$.

In conclusion, Archive 2190 is an account book of Hospitaller properties in Hispania, comprising Catalonia and Languedoc, that was compiled in Rhodes following the death of Juan de Heredia. The new Master, Philip de Naillac, wanted to determine the amounts of money that Languedoc owed to the Order and to enforce their collection. The Hospitaller properties in that region had undergone considerable reorganization throughout the $14^{\text {th }}$ century. By the end of the century their affiliation was still not affixed to either the priory of Catalan or the priory of St. Gilles, but was determined by their commander. The accounts show that the commander, not the house, was personally responsible for paying the responsions. If he held more than one house he could use revenues from one to make up for another. Therefore, whenever possible, Naillac assigned priories such as Bajoles to his own followers in order to enforce collection. The account book gives us the amounts that each house paid in responsions, whereas other sources do not provide a detailed breakdown of sums. We still do not know what the total income of the priories was. The account book, however,

\footnotetext{
${ }^{33}$ Malta, Valletta, National Library, Archive 2190, fol. 1 r; RAYBAUD, pp. 352-353.

${ }^{34}$ Malta, Valletta, National Library, Archive 2190, fol. $1 \mathrm{r}$.

${ }^{35}$ Ibid., fol. $13 \mathrm{r}$.

${ }^{36} \mathrm{Ibid}$., fol. $16 \mathrm{r}$.

${ }^{37}$ Ibid., fols. 39 r, . 62 v, 88 v.
} 
remains a valuable source for the disposition of Templar properties within the Priory system of the Hospital and the personal ties of houses to commanders in addition to information about income.

\section{RÉSUMÉ}

La dissolution de l'ordre du Temple en 1321 entraîna une réorganisation profonde des anciennes propriétés templières dans toute l'Europe. La plupart d'entre elles devinrent la propriété de l'ordre de l'Hôpital, qui dut alors réorganiser ses possessions en Espagne et en France et céder ses domaines valenciens au nouvel ordre de Montesa. Cette réorganisation importante est peu attestée dans les archives principales de l'ordre de l'Hôpital à Malte. Pourtant, un livre de compte, Receptarum linguae hispania (Arch. 2190), récemment découvert dans les archives maltaises, fournit de nouveaux renseignements sur l'organisation et les revenus des prieurés hospitaliers de Saint Gilles en Languedoc et Catalogne pendant les années suivant la mort du maître aragonais Juan Fernández de Heredia. L'archive 2190 comprend les comptes pour les années 1397-1402, groupés par sénéchaussées, prieurés et maisons. L'analyse minutieuse de l'arch. 2190 nous permet de voir comment le nouveau maître, Philippe de Naillac (ancien prieur de Auvergne), dispersa les propriétés pour exclure les partisans de Hérédia et pour percevoir des responsions. Ce livre est aussi une source précieuse d'informations sur la disposition des propriétés templières transférées dans le système de prieurés hospitalier.

\section{SUMMARY}

The dissolution of the Order of the Temple in 1312 created a massive reorganization of former Templar properties throughout Europe. Most of the properties passed to the Order of the Hospital, which then had to reorganize its properties in Spain and France and surrender its lands in Valencia to the new Oder of Montesa. There is little evidence in the main Archives of the Order of the Hospital in Malta for this massive reorganization. But the recent discovery of an account book entitled Receptarum linguae hispania (Archive 2190) in the Malta archives provides new information about the organization and income of Hospitaller priories of St. Gilles in Languedoc and Catalonia immediately following the death of the Aragonese Master Juan Fernández de Heredia. Archive 2190 contains the accounts for years 1397-1402 organized by senescalia, priories, and houses. A careful analysis of Archive 2190 suggests how the new Master, Philip de Naillac (former prior of Auvergne) dispersed the properties described in the book to remove Heredia's adherents and to collect responsions. Finally, it is a valuable source for the disposition of Templar properties within the priory system of the Hospital 